\title{
The use and benefits of information communication technology by Polish small and medium sized enterprises
}

Celina Sołek-Borowska, Warsaw School of Economics, Poland, csolek@sgh.waw.pl

\begin{abstract}
Despite the significant contribution that information communication technology (ICT) has made to business, prior studies indicated that there is a large number of unsuccessful ICT implementations in small and medium sized enterprises (SMEs). Moreover, literature also indicated that SMEs' utilization of ICT tools is reported to be low worldwide, while that is also the case with Polish SMEs. This paper was aim to identify the ICT tools used by Polish SMEs, the areas in which they are used, and the benefits companies perceive from such use. Findings of this research study with 153 Polish SMEs suggest that the most popular ICT tool is email, used by $88 \%$ of surveyed entities. Emails contain knowledge and information that is not codified in any knowledge repository. The main area of enterprise where employees use new technologies is marketing, as confirmed by 44\% of the surveyed entities. About 59\% of the companies surveyed recognize that the use of new technologies brings benefits, which translate into an increase in the company's profits. To stimulate the development of SMEs Polish companies, this study found that it is important to support the development of modern ICT tools for economic growth.
\end{abstract}

Keywords: Information communication technology (ICT) tools, ICT use, ICT benefits, small and medium sized enterprises (SMEs).

\section{Introduction}

Small and medium size enterprises (SMEs) play an important role in economic development by creating employment, while helping to raise the income levels of a majority of the people both in developed and developing countries. These enterprises are the driving force for Gross Domestic Product (GDP) growth. Moreover, prior research indicated that SMEs bring considerable innovation (Ongori \& Migiro 2010). The economic growth of any country is closely linked with SMEs' development. According to Chibelushi (2008), "For many SMEs innovation is not about "blue-sky" research and leading edge technology, but rather the adoption of new technologies to enhance efficiency and effectiveness" (p. 725). The flow of information and the development of information technologies are currently the foundation for the development of competitiveness. Moreover, it is an impulse for the economic and social development of each country (Polish Agency of Entrepreneurship Development, 2017). SMEs' effective use of Information Communication Technology (ICT) has a significant influence on their competitiveness and sustainability (Ongori \& Migiro 2010). ICT tools are the facilitators in acquiring information and changing it into knowledge, which in turn becomes a prerequisite for winning clients and increasing the company's value. 
By analyzing literature on ICT use, it can be noticed that the subject of ICT adoption has been investigated thoroughly in academic papers all over the world, but not in Poland. This is a natural consequence of fast and constant rate of ICT development and the progress of Internet diffusion worldwide. The growing number of Internet users has allowed SMEs to increase the number of potential customers located in many countries. Prior studies identify many benefits achieved by SMEs, such as: closer working relationships among value chain partners, lower costs of coordination, communication and information processing, increased productivity, enhanced efficiency and effectiveness, greater access to market information and knowledge, acquiring information system capabilities to support business transformation, as well as better customer responsiveness locally, regionally, or globally (Abouzeedan \& Busler, 2002; Alam, Khatibi, Ismail, \& Ahmad, 2005; Balocco, Mogre, \& Toletti, 2009; Kotelnikov, 2007; Vidgen, Francis, Powell, \& Woerndl, 2004). The low adoption and success rate of ICT may be attributed to tendency of SME to be risk adverse, that aspect distinguishes them from larger organizations (Nguyen, 2009).

Alam and Noor (2009) noted that the majority of the empirical research related to ICT adoption is based on large companies and that usually SMEs are characterized as lacking knowledge about the possible advantages of ICT. But the use of ICT can improve business competitiveness, with the Internet, providing opportunities for SMEs to compete equally with larger enterprises (Alberto \& Fernando, 2007). Furthermore, it has been recognized that not all SMEs have to implement ICT tools in the same level of complexity. It can be stated, that there is no "one-sizefits-all" ICT policy across different industries, as different sectors use ICT differently and will adopt them at a different pace (Kotelnikov, 2007). Therefore, there is a need of holistic examination of ICT adoption by looking at the tools that are used by Polish SMEs and the benefits these tools bring. Moreover, although the literature review highlights the importance of ICT adoption it also finds a major lack of research on ICT adoption amongst SMEs. This paper undertakes to fill this gap in the context of Polish small and medium sized enterprises as part of the Statutory Research executed by the Management Institute (KZiF/S/35/16).

This research is particularly relevant to Poland, where the country faces the challenge of replacing current growth drivers such as low labor costs, European Union (EU) subsidies and productivity growth through the computerization that may become the driving force of economic growth generally. Although Poland is one of the most dynamically developing economies in the EU, the low level of digitization is a feature of the domestic market. According to the Digital Economy and Digital Society Index (DESI) for 2017, Poland ranks $23^{\text {rd }}$ in the group of 28 EU Member States. EU policy highlights that the smart use of ICT is an important success factor for the competitiveness of European companies, in particular for SMEs (European Commission, 2008). As noted by the Polish Agency of Entrepreneurship Development (2016), research attention up till now has been mostly directed to large companies with Polish subsidiaries rather than Polish SMEs, even though Poland has the sixth largest number of SMEs in the EU and these companies contribute half the Polish GDP. The next section provides an overview of Internet based ICT adoption, followed by an explanation of the research methodology and an analysis of the research findings. The concluding section provides a discussion of the results in the light of the extant literature, and suggestions for future research. 


\section{Literature Review}

\section{Internet-Based ICT Use}

Currently, economies witness for the first time in the history the impact of technology evolution on the way that businesses operate. As indicated by prior literature:

"First, it has changed the industry structures and altered the degree of competition. Second, it has created a competitive advantage for the businesses, which have adopted ICTs in their business processes. Third, it has affected business operations. These changes compel SMEs to adopt ICTs in their business processes to cope with these challenges in their business environment." (Ongori, 2008, pp. 13-14)

The term ICTs can be defined in a wide sense as technologies dedicated to information storage, processing, and communication (Rao, 2004, p. 262). Kotelnikov (2007) offered a detailed explanation on the level of ICT usage among the SMEs, which can range from a basic technology to more advanced ones:

"radio, fixed lines, or mobile phone to more advanced technology such as e-mail, or information processing systems. The next ICT advancement is associated with a personal computer (PC) with basic software. Even without Internet connectivity, SMEs can use PCs for basic word processing, accounting, and other business practices. The use of advanced ICT to improve business processes falls into the category of e- business.” (p. 29)

Having access to the Internet, SMEs are able to use more advanced communication tools as pointed out by Tan, Choy, Lin, and Eze (2010) such as: e-mails, file sharing, creating websites, and e-commerce. However, the SMEs operating in the production sector may adopt more complex Information Technology (IT) tools such as the Enterprise Resource Planning (ERP) or inventory management software. While use of ICT appears to be highly beneficial to companies, Kotelnikov (2007) noted that not all SMEs need to use ICT to the same degree of advancement. SMEs may adopt these tools gradually starting from simple tools or jump immediately to advanced ICT capabilities. Adoption depends on many factors, including the maturity of the SMEs or the presence of regional and foreign markets. In this paper, Internet based ICT adoption is generally referred to as to the use of ICT tools, which consist of computers and software. Particularly, adoption means the decision to use Internet-based ICT to communicate and/or conduct business with stakeholders.

\section{ICT Benefits}

Adoption of ICTs could potentially provide many benefits inside and outside business processes or transactions. ICTs' adoption was documented in prior literature to improve information flow and knowledge management in companies, reduce transaction costs, increase the speed and reliability of transactions for both business-to-business (B2B) as well as business-to-consumer (B2C) though the use of e-commerce (Ongori \& Migiro, 2010). In addition, ICT tools were found to help improve external communications and quality of services for current or new customers (OECD, 2004). Similar to large businesses in the global market, access to information is a critical factor for the success and survival of SMEs (Rasmussen, 1997). Effective use of ICT enables SMEs to compete with large business by selling their products to international markets 
(Ramsey, Ibbotson, Bell, \& Gray , 2003). Thus, ICTs can be used as a foundation on which to base the business strategy of SMEs (Maguire, Koh, \& Magrys, 2007). Jones, Davies, and Muir (2003) pointed to the saving aspect of ICT adoption in terms of cost and time. Alam at al. (2005) emphasized the ability of SMEs to reach global markets and achieve low cost communication. Since SMEs improve competitiveness of national economies, these factors collectively bring positive through job creation and revenue generation. Governments, therefore, have an interest in the promotion of access to and use of ICTs by SMEs (Mutula \& Brakel, 2006). ICTs' use expands information and knowledge management within the company, reduces transactions cost, as well as increases the speed of transactions for both businesses and consumers. Additionally, ICTs are effective tools for improving external communication and quality of services for current and new customers (Lukacs, 2005; Rosemary \& Craig, 2004). To summarize, it can be stated that ICTs have the potential to generate a step change among SMEs and make them more competitive, while stimulate innovative. As the world economies continue to move towards increased integration of advances in ICTs, SMEs are likely to derive these benefits by participating in both regional and international markets. ICTs' adoption in SMEs is critical for their survival in this era of globalization (Ongori \& Migiro, 2010).

\section{Methodology}

This section presents results from a subset of data gathered as part of a larger research project into Polish SMEs carried out by the Institute of Management at the Warsaw School of Economics (Statutory Research of Management Institute, 2016) on a sample of 153 companies. Whilst the larger research project aims to describe the Polish SMEs environment, a subset of the data was analyzed (Sołek-Borowska, 2017a, b) with a view to identifying the knowledge management systems in use at these companies. Consequently, the focus of this paper is on the particular ICT tools that the SMEs utilize in their daily operations. This study tried to achieve a representative sample in order to describe the Polish SMEs landscape in general. Table 1 summarizes the composition of the sample in this study. Therefore, the data on ICT systems used by SMEs is analyzed, which complements the research from 2016 (Statutory Research of Management Institute, 2016). The research in 2017 studied 200 SMEs in Poland and the questions focused on what ICT systems these companies utilize. Its aim was to find out why there is a low usage of ICT tools amongst SME's investigated one year earlier (Sołek-Borowska, 2017a).

The research questions that this study addressed were as follows:

RQ1: What ICT tools do Polish SMEs use?

RQ2: In which business area are these tools used?

RQ3: What benefits do these companies perceive from ICT utilization?

RQ4: What ICT systems do SMEs utilize? (Integrated systems as opposed to standalone tools) 
Table 1. Features of investigated companies $(\mathrm{N}=153)$ (Statutory Research of Management Institute, 2016)

\begin{tabular}{|l|c|c|}
\hline Enterprise & $\boldsymbol{N}$ & \% \\
\hline Type of Business & & \\
\hline Production & 75 & $49 \%$ \\
\hline Trade & 41 & $27 \%$ \\
\hline Services & 37 & $24 \%$ \\
\hline Form of ownership & & \\
\hline Ltd. & 122 & $80 \%$ \\
\hline Joint stock company & 21 & $14 \%$ \\
\hline Sole proprietor & 10 & $6 \%$ \\
\hline Type of capital & & $88 \%$ \\
\hline Majority of Polish capital & 135 & $12 \%$ \\
\hline Majority of foreign capital & 18 & $50 \%$ \\
\hline Scope of activity & 77 & $41 \%$ \\
\hline International & 63 & $9 \%$ \\
\hline National & 13 & $50 \%$ \\
\hline Regional/ local & & $50 \%$ \\
\hline Number of employees & 77 & \\
\hline $10-49$ persons & 76 & \\
\hline $50-249$ persons & & \\
\hline
\end{tabular}

The questions were asked in order to assess how advanced Polish SMEs are in terms of the adoption of ICT tools like emails, video conferences, and IBM solutions. SMEs are very close to their customer base and, therefore, this study was seeking to assess the business area that the company use ICT tools. This research was used the Computer Assisted Telephone Interviewing (CATI) method. The questionnaire was answered by managers $(87.5 \%)$ and company owners $(12.5 \%)$. Assuming that the owner/founder of the SME is a key figure and has a significant decision making power, very often such an individual decides about the purchase and implementation of particular ICT systems. Thus, this study attempted to determine which ICT systems are the most popular.

\section{Research Findings and Analysis}

\section{ICT tools used by small and medium sized enterprises}

The emergence of new ICTs, from simple e-mail accessible from anywhere via the Internet and Intranet, more sophisticated audio and video conferencing, common electronic boards or groups established in the network have helped businesses significantly overcome the distance and time barrier. Technical infrastructure is meant to be an important facilitator in a knowledge-based economy. Such an infrastructure plays a critical role in the organization's knowledge management system. To create, use, and share new knowledge, the exchange of existing knowledge must be facilitated through the introduction of different technology platforms (SołekBorowska, 2017b).

To create knowledge sharing opportunities, an organization must develop a comprehensive IT infrastructure. Knowledge can be created and transferred in the organization using technical 
infrastructure. Technology includes tools, systems, platforms and automated solutions that affect the development, use, and distribution of organizational knowledge (Coukous, 2001). These include chat, SharePoint, Skype, electronic boards, team viewer, and Google platform. Technological platforms can help to stimulate the flow of knowledge, but their impact on knowledge sharing must be investigated when taking into account a cultural and organizational context to see how employees are encouraged to develop and share their knowledge (Clarke \& Rollo, 2001). Respondents were asked what ICT tools they usually used for knowledge sharing. The results are presented in Figure 1.

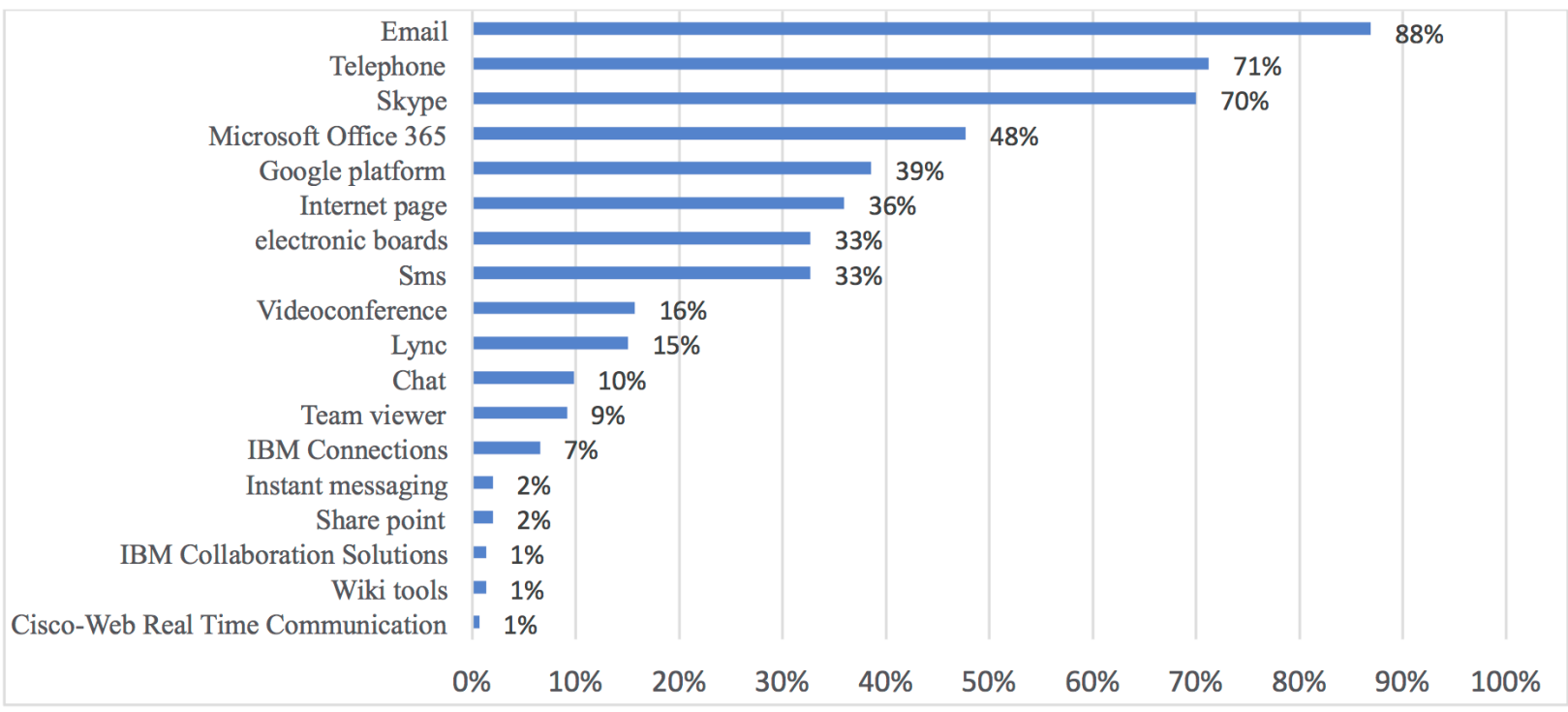

Figure 1. Tools Used for Knowledge Sharing based on data from Statutory Research of Management Institute (2016) (N=153)

The most popular and widely used instrument in the knowledge sharing process is email, used by $88 \%$ of the surveyed companies. Today's businesses live in modern times when every day business owners are overwhelmed with emails. However, $71 \%$ of respondents are still using the traditional landline telephone. This may be due to habit: the landline phone is a confirmation of the company's existence. Nowadays, there are many platforms through which one can contact a partner, a contractor, or even have the opportunity to see them. In third place, respondents indicated Skype - 70\%. Skype offers the opportunity to make free online calls for a small fee and to make landline calls at home and abroad. Skype's advantage is the ability to make video calls, the ability to split the screen and the ability to chat with several people at the same time; it also offers an application that can be installed on mobile devices. It appears that the most often used ICT tools are the traditional ones, meaning there is significant scope for improvement (SołekBorowska, 2017b).

\section{Areas of ICT use}

The development of Internet and Internet-based technologies strongly favors small and medium enterprises by providing tools that make it much easier to optimize their operations and, above all, expand their circle of clients. The wealth of services offered over the Internet also makes it particularly beneficial SMEs. According to Brzozowski (2010), these benefits are, among others: 
- Global auditorium

- Interactivity

- The possibility of adapting to the individual needs of the recipient

- Relatively low communication costs

- Attractive form of communication (animations, music, video sequences, etc.)

- Lack of temporary and spatial restrictions on access

- Relative ease of use (intuitive interface)

- Low level of regulation

- A system of easy connection with documents referenced in the application (hyperlinks)

- Standardization of the transmission protocol

- Easy to update

The key advantage of SMEs is the fact that these companies are closer to the 'client,' especially if the relationship is long established. Therefore, they can dispense with intermediaries while achieving service improvements and reducing costs. On the other hand, the client becomes more demanding. They have the right to comment on product features, express her/his opinion, and become an active creator of new products or their improvement by being a 'prosumer.' More than ever before, the client has gained the right to comment on the product and the company on an extremely significant scale. Comments expressed by Internet users can be both positive and negative, while Internet users immediately notice any attempt to "clean up" negative comments. In an increasingly competitive market, the key factors in a company's success change. Traditional elements of competitive advantage such as product quality or price are replaced by the quality of the company-customer relationship. Accordingly, respondents were asked in which areas SMEs use new communication technologies, the results are presented in Figure 2.

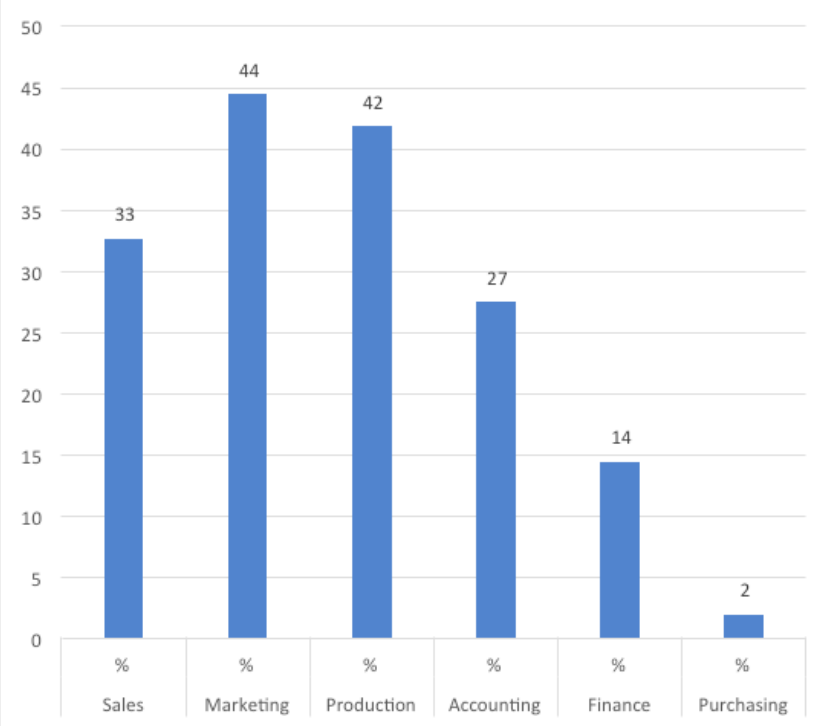

Figure 2. Areas of new technology used based on data from Statutory Research of Management Institute (2016) $(\mathrm{N}=153)$ 
It is not surprising that the area of the enterprise in which employees use new technologies is marketing, as confirmed by $44 \%$ of the surveyed entities. The purchasing department is represented by only $2 \%$ of the surveyed entities, which may result from the fact that there is no separate purchasing department in SMEs and often these functions are assigned to the marketing department. The second key area where new technologies are used is the production department $(42 \%)$, which may result from the automation of the production process.

\section{Benefits of Internet Based ICT Use}

The identification of specific business benefits should be the basis for any decision to use new solutions in the area of new technologies to support business processes in the company. Even if the direct purchase cost of these solutions is small or subsidized by external entities, it should always be justified by the business need. Therefore, an important research area is to answer the question: are SMEs perceive the benefits of using new technologies in accordance with the concept of sustainable development? Generally, among the benefits resulting from changes in the operational model due to the introduction of new ICT solutions that support the implementation of processes between enterprises, it can distinguished, among others, the benefits of process automation. Automation resulting from the application of new ICT tools usually consists in eliminating the work of people in the processes taking place in the enterprise and replacing the paper flow with the flow of data in an electronic form. This is usually connected with the reduction of costs and the shortening of the process implementation time, which translates into financial benefits that is confirmed by the research results presented in Figure 3. In addition, ICT tools are also an opportunity for company development and cooperation with other companies. A company that can support IT systems and use the latest ICT tools is able to reach new potential business partners faster, set rules faster and start cooperation with new partners. Figure 3 presents the benefits that SMEs can gain as perceived by the company.

It is comforting that enterprises recognize that the use of new ICTs bring benefits. These benefits translate into an increase in the company's profits, which was confirmed by $59 \%$ of the surveyed entities. Image-related issues were in second place - 52\% of respondents. Enterprises also notice that their relations with stakeholders have improved $-44 \%$ of responses. A relatively low percentage of answers (8\%) emphasized the ability to notice local problems and get involved in local initiatives. This result is surprising because it is considered that SMEs as local companies embedded in a given community have the best opportunities to solve local problems. SMEs care about the natural environment, which is confirmed by $40 \%$ of respondents. About $21 \%$ of respondents see significant savings through lower consumption of paper and energy. These results are consistent with Ongori and Migiro (2010), who stated that ICTs adoption by SMEs increases the productivity and efficiency of internal business operations, while connecting SMEs more easily and cheaply to external contacts locally or globally. 


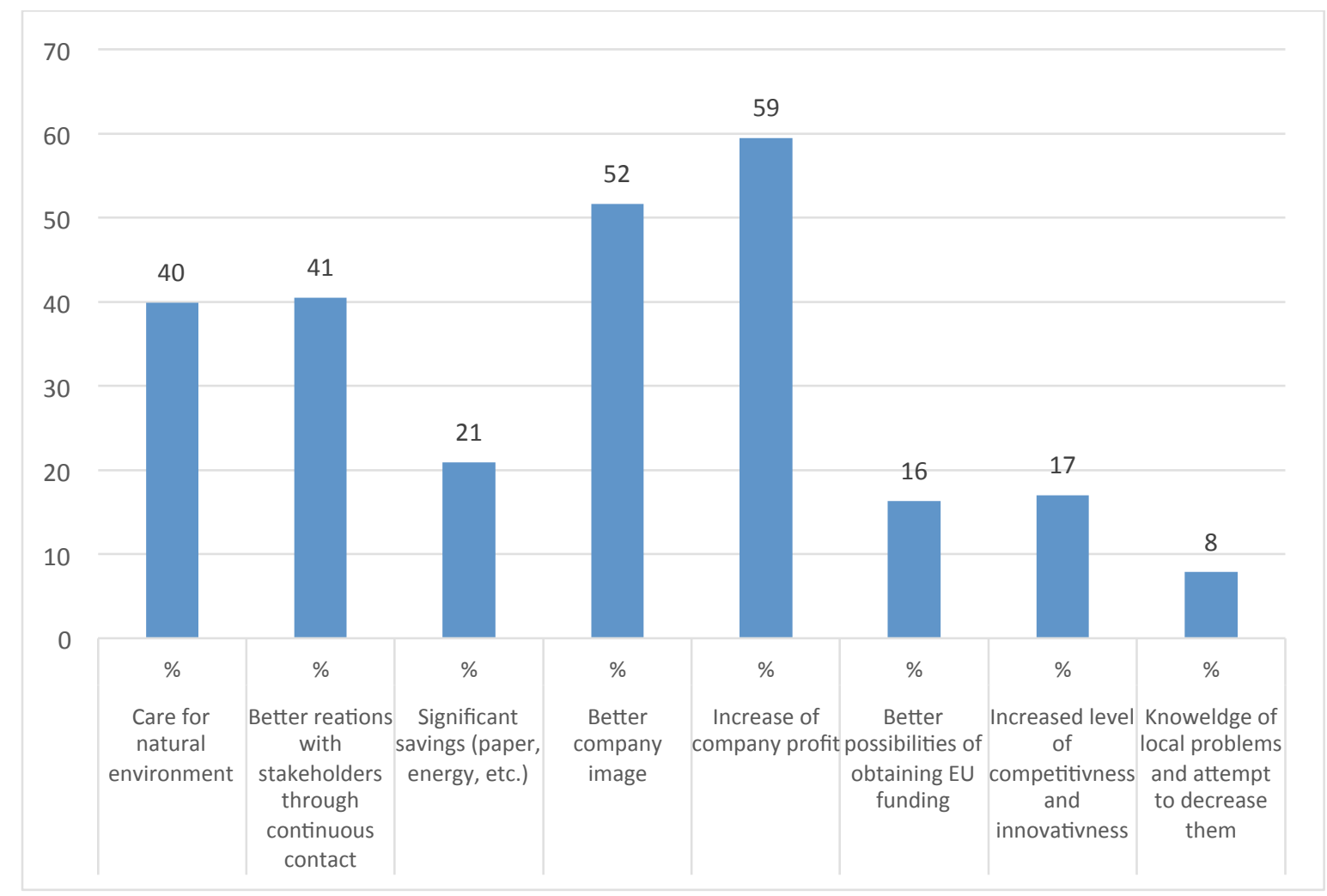

Figure 3. Benefits of Internet based ICT adoption based on data from Statutory Research of Management Institute (2016) (N=153)

\section{ICT Systems Utilized by SMEs}

The development of contemporary enterprises is inseparably connected with the use of ICTs. Because of the growing complexity of connections within the company and its relationship with the external environment there is a need to implement new and updated information systems supporting Supply Chain Management (SCM) and Customer Relationship Management (CRM). The next stage may be the creation of software integrating, distinctive systems into one system of Strategic Enterprise Management (SEM) (Sadza, 2001). Companies more often decide to implement Knowledge Management System (KMS) when they appreciate the value of information and knowledge.

Enterprises often face a dilemma about whether it is better to buy a ready-made solution, or to build a KMS from scratch and adapt it to their own specific needs. The basic problem with ready-made products is that the ontologies and mechanisms coded in them do not always correspond to the organization's needs. KMSs are implemented in order to meet the expectations of the high-level management in relation investment returns or to increase the effectiveness of the company. Unfortunately, these expectations often remain unfulfilled, because the main emphasis is placed on the technological side of the enterprise, forgetting to take into account the strategy of the company and the final buyer (Jashapara, 2014). Survey respondents were asked 
what ICTs are used in their companies. Respondents had a choice to pick from the given list or include the ones designed for their particular use. The data is presented in Figure 4.

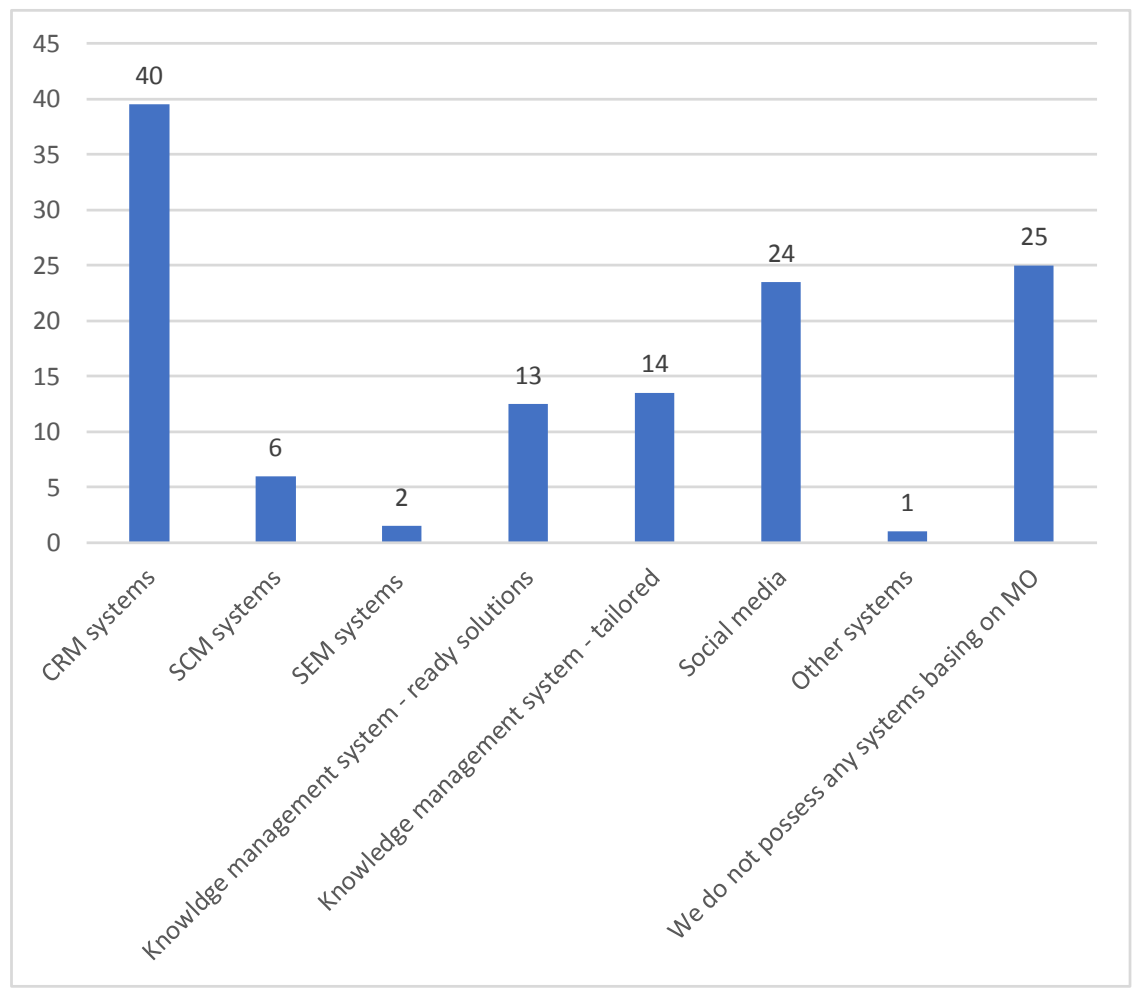

Figure 4. ICT Systems Used by Polish SMEs based on data fromStatutory Research of Management Institute (2017) (N=200)

Unfortunately, a quarter of SMEs still do not have any ICT, using only the Office package, although $24 \%$ of surveyed enterprises use social media. CRM systems are the most popular, as they are present in $40 \%$ of surveyed enterprises. SMEs are well aware that the customer generates income for the company, and the knowledge of their habits, preferences and frequency of purchase is necessary to properly profile the offer. CRM systems also facilitate the building of relationships with clients. The research results are consistent with Greenberg (2010) who stated that the demand for CRM technology has grown as more organizations recognize the importance of better customer relationships, customer knowledge, and customer retention. KMSs are found in only a few enterprises, and the difference between a ready-made solution (13\%) and a tailormade program (14\%) is only one percentage point. SCM systems and Integrating Several Programs (SEM) represent are small percentage in the surveyed companies, $6 \%$ and $2 \%$ respectively.

Because of their size, SMEs are focused on the purchase of ready-made, easy-to-use, understandable ICT solutions that will not require an extensive IT department. For this, they expect that the possible return on investment will be in the short term. Small companies rarely focus on long-term investments in the ICT area, which changes very quickly. They do not have 
facilities in the form of extensive IT departments that could maintain and develop IT systems for a long period of time. For this reason, most small businesses are limited to having the necessary basic ICT tools.

\section{Discussions}

\section{Conclusions}

SMEs represent an important segment of the economy and constitute its economic backbone. They play an important role by creating jobs and contributing to socio-economic development (Wolcott, Mehruz, \& Qureshi, 2008). SMEs should enhance their competitiveness not only in local but also global markets by including Internet-based ICT in their daily operations. To achieve this shift, SMEs must identify the benefits it brings and to remove the barriers that hinder such adoption. Meanwhile, it is worth noting one key issue for SMEs, that the adoption of ICT must outweigh the investment and maintenance costs. In summery, it can be concluded that Polish SMEs belong to the group of 'turtles', namely entities where the level of use of new technologies is less than 30\%: the leading examples of technologies used here are the computer, Internet access and implementation of MS Office. The 'turtles' typology was developed by Boston Consulting Group (2011), by analyzing companies from the SME sector in 2014 identified the following types of companies: technological turtles, technological hares and technological cheetahs.

The most popular and commonly used instrument is the email, used by $88 \%$ of entities. Emails contain knowledge and information that is not codified in any knowledge repository. The feature of a knowledge-based economy is receiving large amounts of information every day using mass media and, above all, emails. In second place is still the landline phone - 71\% of respondents. This may be due to habit, as there are many platforms with which to contact your partner or contractor, including being able to see them. In third place, respondents indicated Skype - 70\%. Skype offers the possibility of making free online calls with few interlocutors for a small fee for calls to landlines in their country and abroad.

It is comforting that enterprises recognize that the use of new ICTs bring benefits. These benefits translate into an increase in the company's profits, which was confirmed by nearly $60 \%$ of the surveyed entities. The second place included image issues, with slightly over $50 \%$ of respondents. Enterprises also notice that their relations with stakeholders have improved - 44\% of responses. SMEs care about the natural environment, which is confirmed by $40 \%$ of respondents. It is not surprising that the area of the enterprise in which employees use new ICTs the most is the area of marketing confirmed by $44 \%$ of the surveyed entities. The second key area where new technologies are used is the production department - 42\%, which may result from the use of automation in the production process.

This research confirms that compared to large enterprises, SMEs rarely invest in new ICTs because of limited financial resources (Nunes, Annansingh, Eaglestone, \& Wakefield, 2006). Many of these companies still rely on traditional methods of storing data in files or folders on a hard disk in a computer (Egbu, Hari, \& Renukappa, 2005), which is in line with earlier research results. Public knowledge and information stored must be appropriate and truthful to prevent 
mistakes. Documents must be filtered by managers or authorized personnel before they are saved and made available to other employees to maintain the quality of the databases (Wong \& Aspinwall, 2005). Low-level use of ICTs is reflected in the low adoption of KMSs. For SMEs to move from a simple email to advanced KMS is a huge jump, but it is reassuring that $40 \%$ use CRM. In response to the growing market of sole proprietors, other companies have begun to produce simple CRM systems in the cloud that facilitate their work. When running a sole proprietorship, the company owner has to remember about many important issues and important deadlines - not so much in relation to the clients and the liabilities incurred towards them, but also settlements with offices or suppliers. A simple online CRM system allows them to list the necessary steps that should be performed on a given date. CRM online is not only meant to remind small business owners of their clients, but also to facilitate cooperation with them (Rozwój jednoosobowej działalności gospodarczej przy wsparciu CRM online, 2016). At the same time, the means to improve the computerization of companies in the SME sector is to support solutions that meet their needs and financial capabilities. Taking these two factors into account, it is worth promoting solutions that are tailored to the needs of SMEs and within which innovative IT service models are offered, making them affordable for SMEs at the same time. The promoted solutions should ensure compatibility with other products used on the market and be compatible with the technical standards on the market. To stimulate the development of companies from the SME sector in Poland or other countries, it is important to support the development of new ICTs along with education about such systems. To respond to such a challenge the Google subsidiary in Poland offers many analytical tools free of charge as well as free training. The Google digital garage (a programme developed by Google) has been run for SMEs to raise the level of ICT adoption (Google n.d.).

\section{Limitations, Implications, and Direction of Further Research}

This study had a limited sample size and could be further expanded to include a larger sample for better generalizability of results. Cross-country comparison might provide interesting insights. Further in-depth research can be carried out on the issues raised in this paper both in Poland or other countries. This paper has some important implications. The findings suggest that ICT adoption is no longer a choice but a must across the different types of SMEs. The SMEs ought to be aware that they need to be innovative not just by offering unique products and services but also through the adoption of the latest technology to complement their market offerings and strengthen their internal operations. This research confirms that CRM is the most often used ICT system because of importance placed on customer behavior. Much work needs to be done to raise awareness of the potential of the strategic adoption of ICT for business growth, to identify new business opportunities (innovation) and to maintain a stable company competitive market position.

\section{References}

Abouzeedan, A., \& Busler, M. (2002). Information technology (IT) impact on performance of small and medium enterprises (SMEs). Proceedings of RENT XVI, Research in Entrepreneurship and Small Business, Barcelona, Spain, pp. 127-56. 
Alam, S. S., Khatibi, A., Ismail, H., \& Ahmad, S. (2005). Perceived benefits of e-commerce adoption in the electronic manufacturing companies in Malaysia. Journal of Social Sciences, 1(3), 188-193.

Alam, S. S., \& Noor, M. K. M. (2009). ICT adoption in small and medium enterprises: An empirical evidence of service sectors in Malaysia. International Journal of Business and Management, 4(2), 112-125.

Alberto, B. M., \& Fernando, L. L. (2007). A firm-level analysis of determinants of ICT adoption in Spain. Technovation, 27, 352-366.

Boston Consulting Group, (2011). How Internet makes the transformation of the Polish economy, Warszawa. Retrieved from: http://www.bcg.com.pl/documents/file78280.pdf

Balocco, R., Mogre, R., \& Toletti, G. (2009). Mobile Internet and SEMs: A focus on the adoption. Industrial Management \& Data Systems, 109(2), 245-261.

Chibelushi, C., (2008). Learning the hard way? Issues in the adoption of new technology in small technology oriented firms. Education + Training, 50(8/9), 725-736.

Clarke, T. \& Rollo C. (2001). Capitalising knowledge: Corporate knowledge management investments. Creativity and Innovation Management, 10(3), 177-188.

Egbu, C. O., Hari, S., \& Renukappa, S. H. (2005). Knowledge management for sustainable competitiveness in small and medium surveying practices. Structural Survey, 23(1), s. 721.

European Commission, 2008. Fostering SME's growth through digital transformation. Retrieved from: http://ec.europa.eu/DocsRoom/documents/19646

Google (n.d.). Internet revolutions. Retrieved from: https:/learndigital.withgoogle.com/ internetowerewolucje

Greenberg, P. (2010). The impact of CRM 2.0 on customer insight. Journal of Business \& Industrial Marketing, 25(6), 410-419.

Jones, P., Davies, P. B., \& Muir, E. (2003). E-business barriers to growth within the SME sector. Journal of Systems and Information Technology, 7(1), 1-25.

Kotelnikov, V. (2007). Small and medium enterprises and ICT. United Nations Development Program-Asia Pacific Development Information Program and Asian and Pacific Training Center for Information and Communication Technology for Development, Bangkok.

Lukacs, E. (2005). The economic role of SMEs in world economy, especially in Europe. European Integration Studies, Miskolc, 4(1), 3-12. Retrieved from: http://www.unimiskolc.hu/uni/res/kozlemenyek/2005/EIS1.doc

Maguire, S., Koh, S. C. L., \& Magrys, A. (2007). The adoption of e-business and knowledge management in SMEs. Benchmarking: An International Journal, 14(1), 37-58.

Mutula, S. M., \& Brakel, P. V. (2006). E-readiness of SMEs in the ICT sector in Botswana, with respect to information access. The Electronic Library, 24(3), 402-417. 
Nguyen, T. H. (2009). Information technology adoption in SMEs: An integrated framework. International Journal of Entrepreneurial Behaviour \& Research, 15(2), 162-186.

Nunes, M. B., Annansingh, F., Eaglestone, B., \& Wakefield, R. (2006). Knowledge management issues in knowledge intensive SMEs. Knowledge Management Issues, 62(1), 101-119.

OECD (2002). Measuring the information economy. Retrieved from: http://www.oecd.org/document/5/0,2340,en $2649344492765701 \quad 1 \quad 1 \quad 1 \quad 1,00 . h t m l$

Ongori, H. (2008). Barriers to ICTs adoption by SMEs: Evidence from a developing country perspective. Indian Journal of Management, 1(1), 12-17.

Ongori, H., \& Migiro, S. O. (2010). Information and communication technologies adoption in SMEs: Literature review. Journal of Chinese Entrepreneurship, 2(1), 93-104.

Polish Agency of Entrepreneurship Development (2016). State of small and medium enterprises in Poland, Warsaw. Retrieved from: https://badania.parp.gov.pl/raport-o-staniesektoramsp/stan-sektora-msp-w-polsce

Polish Agency of Entrepreneurship Development (2017). State of small and medium enterprises in Poland, Warsaw. Retrieved from: https://www.parp.gov.pl/images/PARP publications /pdf/raport\%20o\%20stanie \%20sektora\%20msp\%20w\%20polsce_2017.pdf

Rao, S. S. (2004). Role of ICTs in India rural community information systems. Journal of Information Systems, 6(4), 261-269.

Ramsey, E., Ibbotson, P., Bell, J. \& Gray, B. (2003). E-opportunities of service sector SMEs: An Irish cross-border study. Journal of Small Business and Enterprise Development, 10(3), 250-264.

Rasmussen, E. M. (1997), Indexing images. Annual Review of Information Science and Technology, 32, 169-196.

Rosemary, S., \& Craig, S. (2004). Benefits and barriers of electronic marketplace participation: An SME perspective. Journal of Enterprise Information Management, 17(4), 301-311.

Rozwój jednoosobowej działalności przy wsparciu CRM online (2016). Development of sole proprietorship with the support of online CRM. Retrieved from: https://chmiuro.pl/pl/blog/rozwoj-jednoosobowej-dzialalnosci-gospodarczej-przywsparciu-crm-online

Sołek-Borowska, C. (2017a). Knowledge creation processes in small and medium enterprises: A Polish perspective. The Online Journal of Applied Knowledge Management, 5(2), 61-75.

Sołek-Borowska C. (2017b). Knowledge sharing processes in small and medium enterprises. Business Informatics, 107-117. Retrieved from: http://businessinformatics.ue.wroc.pl/

Statutory Research of Management Institute (2016). Financed by Collegium of Management and Finance, Warsaw School of Economics, Poland.

Statutory Research of Management Institute (2017). Financed by Collegium of Management and Finance, Warsaw School of Economics, Poland. 
Tan, K. S., Choy, Ch. S., Lin, B., \& Eze, U. C. (2010). Internet-based ICT adoption among SMEs: Demographic versus benefits, barriers, and adoption intention. Journal of Enterprise Information Management, 23(1), 27-55.

Vidgen, R., Francis, D., Powell, P. \& Woerndl, M. (2004). Web service business transformation: Collaborative commerce opportunities in SMEs. Journal of Enterprise Information Management, 17(5), 372-381.

Wolcott, P., Mehruz, K., \& Qureshi, S. (2008). Meeting the challenges of ICT adoption by micro enterprises. Journal of Enterprise Information Management, 21(6), 616 - 632.

Wong, K. Y., \& Aspinwall E. (2005). Knowledge management: Case studies in SMEs and evaluation of an integrated approach. Journal of Information \& Knowledge Management, $4(2), 95-111$.

\section{Author's Biography}

Celina Solek-Borowska, Ph.D. is Assistant Professor at the Warsaw School of Economics, Poland. She also serves as a business consultant. Her research interests focus on knowledge creation and sharing practices amongst businesses and universities, competition in the higher education sector, and teamwork. She has taught on the Erasmus program for the University of Gran Canaria, the University of Hertfordshire, and the University of Alicante. 